\title{
References
}

Arifin, M., 1983. Enlargement of teak planting space in tumpangsari. Duta rimba (Indonesia) 57/58 (9): 24-26.

Atmosoedarjo, S. \& S. G. Banyard, 1978. The prosperity approach to forest community development in Java. Commonwealth Forestry Review 57(2): 89-98.

Hart, H. J. M., 1928. Stem number and thinning: an orientating research after the best plant distance and way of thinning of teak. Communication 21, Forest Research Institute, Bogor, Indonesia.

Filius, A. M., 1981. Economic aspects of agroforestry. In: K. F. Wiersum, Viewpoints on agroforestry. Agricultural University, Wageningen, Netherlands.

Wiersum, K. F., 1982. Treegardening and taungya in Java. Agroforestry Systems (Netherlands) 1: 53-70.

This synopsis is based on a M.Sc.thesis, Department of Forest Management, Agricultural University, Wageningen, 1983. v +61 pp., 15 tables, 4 figs., 4 appendices, 53 refs. English.

Available as paper copy (order R007P, $f 20$ including postage) or microfiche (order R007M, f 12,50 including postage) at: NARD, clo Pudoc, P.O. Box 4, 6700 AA Wageningen, Netherlands (telex 45015 blhwg $\mathrm{hl}$ ).

\section{Economic aspects of diseases and disease control in dairy cattle, with special reference to reproductive failure}

A. A. Dijkhuizen (Department of Farm Economics, Agricultural University, Hollandseweg 1, $6706 \mathrm{KN}$ Wageningen, Netherlands)

Accepted: 16 May 1984

\begin{abstract}
Some years ago systematic research was initiated to improve quantitative insight into the economic impact of animal diseases and their control. The aim of the present study is to increase this insight by (a) further development of the methods used in this field and (b) performing real quantifications.

Key-words: economics, dairy cattle, reproductive failure, fertility control, replacement.
\end{abstract}

Introduction. The economic impact of animal diseases is determined to a large extent by a combination of three factors, viz the form of disease, the animal species and the economic level(s) considered (Renkema \& Dijkhuizen, 1979). At each quantification it is essential to define these factors accurately, in order to decide which elements to consider and how to place an economic value on them. This study concerns the reproductive failure in dairy cattle, seen from the point of view of an 
individual farmer. Herewith three interrelated phases are considered: the financial loss with regard to sub-optimal calving interval and forced replacement, the costs and benefits of fertility control, and the decision whether to (re-)inseminate empty cows within a herd or to replace these.

Material and methods. To study the questions mentioned an economic replacement model of Renkema \& Stelwagen (1979) was adjusted and extended. In the present model individual cows are distinguished, which differ in age (1-14 lactations), calving interval (345-525 days), production level (70-130\% of the age-corrected herd level) and persistence of milk production during the lactation (90-110\% of the agecorrected herd level). Furthermore, a genetic increase in milk production of $1 \%$ per year was assumed, as well as a preference for present over future income (discount rate $4 \%$ per year). Firstly, the model was used to determine the economic optimal calving interval and the norm loss per day lengthening. For that, total incomes of ten intervals were calculated and compared on a yearly basis. Special attention was paid to those benefits and costs which are not proportional to the length of the calving interval, such as milk yield $(\mathrm{kg})$ in current and subsequent lactation, milk fat and protein content, feed costs (including changes in live body weight) and calf sales. Secondly, norm losses per culled cow due to reproductive failure were determined, consisting of the difference between the income a particular cow could earn during her remaining expected life (if the reason for replacement had not presented itself, but with normal probabilities of disposal due to other diseases) and the expected average income of a replacement young cow with normal productive qualities and normal probabilities of disposal, over the same period. Now, special attention was paid to data associated with age (e.g. milk receipts, value of calves, slaughter value of cows, feed costs, costs of a 2-year-old heifer just before calving and probabilities of disposal). Total loss per farm and profitability of fertility control were determined from calving interval data and forced replacement data of 71 farms out of an investigation in Overijssel (Sol \& Renkema, 1984) and norm loss rates described above. Finally, the model was used in deciding whether or not to replace animals: the longer it takes to get a cow pregnant, the more urgent becomes the question, 'Is the loss less when the calving interval is longer or when the cow is culled?' At each heat the criterion for the decision is: a cow should be inseminated with the aim of retention if the sum of expected differences in profits during her remaining expected life in the case of pregnancy, compared with replacement at the optimal stage of the current lactation, still exceeds zero.

Results. The optimal length of the calving interval was calculated to be one year for first-lactation cows and less than one year for older cows. On average, the norm loss per day lengthening of the interval amounted to Dfl. 1-2, and was most affected by the shape of the lactation curve (persistence): the worse the persistence, the higher the norm loss. Moreover the norm loss per day increased with the length of the interval: consequently, one and the same average calving interval of a herd can lead to a difference in loss. The norm loss per culled cow due to reproductive failure was determined to average almost Dfl. 500, which was much less than for disposal due 
to other reasons (Sol et al., 1984). The calculated norm loss decreased with age and increased with the relative production level of the cow concerned.

The calculated total loss per farm amounted to Dfl. 63 per cow per year, of which Dfl. 35.50 resulted from sub-optimal calving interval and Dfl. 27.50 from forced replacement. Including costs for veterinary treatment and drugs, total loss was estimated to be Dfl. 80 per cow per year, which equals about $2 \%$ of the gross production value or $10 \%$ of an average farmer's income. The difference between the $20 \%$ of farms with the highest and the $20 \%$ of farms with the lowest calculated loss was even more than the average loss. Two years of fertility control contributed more to the improvement of insufficient or moderate fertility than to the prevention of a deterioration in herds with excellent fertility. Compared to control farms the programme had a positive effect $(P<0.01)$, which was calculated to average Dfl. 23.50 per cow.

With regard to individual cows within a herd, model calculations showed that first lactation cows which produce (corrected for age and stage of lactation) less than $86 \%$ of the herd level should not be inseminated, but culled for insufficient productive capacity. The critical production level below which it is not worthwhile to re-inseminate first-lactation cows increases to $90 \%$ at 165 days after calving and $95 \%$ at 245 days. The critical levels for second-lactation cows agree with those in the first lactation; for older cows they were higher. From a sensitivity analysis it was concluded that these levels were practically independent of several factors, especially those (e.g. milk price) which affect the expected income of both the cow present in the herd and the replacement cow. The most important influence was determined to be the repeatability of a longer calving interval. If problems with respect to fertility are expected in the cow concerned in future lactations also, one should stop inseminating at an earlier moment in lactation. Further research is needed to make an accurate prognosis for future calving intervals, in particular with respect to repeatbreeders.

Final remark. The economic calculations will be extended by involving other health problems (mastitis) as well as other animals species (sows). Therewith a further development of (stochastic) simulation models will play a central role.

\section{References}

Renkema, J. A. \& A. A. Dijkhuizen, 1979. Economische aspecten van dierziekten, in het bijzonder bij melkvee. Tijdschrift voor Diergeneeskunde 104: 977-985.

Renkema, J. A. \& J. Stelwagen, 1979. Economic evaluation of replacement rates in dairy herds. I. Reduction of replacement rates through improved health. Livestock Production Science 6: 15-27.

Sol, J. \& J. A. Renkema, 1984. A 3 year herd health and management program on 30 Dutch dairy Farms. I. Objectives, methods and main results. The Veterinary Quarterly, in press.

Sol, J., J. Stelwagen \& A. A. Dijkhuizen, 1984. A 3 year herd health and management program on 30 Dutch dairy farms. II. Culling strategy and losses caused by forced replacement of dairy cows. The Veterinary Quarterly, in press.

This synopsis is based on a doctoral thesis entitled 'Economische aspecten van ziekten en ziektebestrijding bij melkvee', State University, Utrecht, Netherlands, 1983. 
$166+27$ (appendix) pp., $6+4$ (appendix) figs., $41+17$ (appendix) tables, appendices, 93 refs. Dutch, English summary.

Available as paper copy (order R008P, $f 30$ including postage) or microfiches (order R008M, f 17,50, including postage) at: NARD, clo Pudoc, P.O. Box 4, 6700 AA Wageningen, Netherlands (telex 45015 blhwg $n l$ ).

\title{
An ideotype of forage maize for north-west Europe
}

P. C. Struik (Department of Field Crops and Grassland Science, Agricultural University, Haarweg 333, 6709 RZ Wageningen, Netherlands)

Accepted: 18 May 1984

\begin{abstract}
Morphological and physiological characteristics of an ideal genotype of forage maize for north-west Europe are described. This ideotype shows an optimum yield of digestible organic matter, is easy to harvest and to preserve, allows a high intake and is efficiently utilized by the ruminant.

Key-words: forage maize, ideotype, genotype, yield, digestibility, dry-matter content, intake, cell wall.

Introduction. An ideotype can be defined as the ideal genotype of a crop, in which the characteristics that maximize productivity and quality under the prevailing conditions and recommended cultural practice are combined. This implies that the ideotype should be realistic and will only be applicable for a defined environment, in this case for the climate and cultivation practices of north-west Europe. The ideotype of forage maize should:

- yield a maximum and stable amount of digestible organic matter

- be easy to harvest and to preserve

- be palatable, nutritious and allow a high dry-matter intake

- be efficiently utilized by the animal.
\end{abstract}

These demands can be translated into some model characteristics, which will be discussed in this paper.

\section{Model characteristics of forage maize in north-west Europe}

High dry-matter yield. Early vigour and cold tolerance are essential. The slow early development requires plant density to be high. Therefore this ideotype must also be a weak intraspecific competitor. To minimize mutual shading during later stages of development, the ideotype must show a prostrate leaf orientation especially of the 